\title{
EKSPLORASI EVALUASI KEPUASAN PELAYANAN PADA KUALITAS JASA PADA PERTAMINA CABANG YOGYAKARTA
}

\author{
AUDITA NUVRIASARI \\ Prodi Manajemen Universitas Mercu Buana Yogyakarta \\ Email: audyta@ymail.com \\ NUR IHSAN \\ Prodi Manajemen Universitas Mercu Buana Yogyakarta \\ Email: iksan nur@yahoo.com
}

\begin{abstract}
ABSTRAK
Peneliti ini bertujuan untuk mengetahui tingkat kepuasan konsumen terhadap kualitas pelayanan jasa SPBU seluruh cabang yogyakarta dan mengenai strategi pelayanan yang perlu diterapkan agar dapat meningkatkan kepuasan konsumen disini dimensi kualitas yang diteliti meliputu (Fasilitas, Intanjibel dan tanjibel) yang dapat seluruh SPBU seluruh cabang yogyakarta. Peneliti mengunakan penedekatan analisis deskeriftif, metode penelitian yang dipakai adalah metode survey, data perimer dikumpulkan melakukan dengan penyebaran kuesioner. Tehnik penghitungan yang dilakukan adalah mean arithmatic dan uji validitas, reabilitas, uji asumsi klasik dan regresi linier berganda.

Hasil penelitian yang diberikan oleh karyawan SPBU adalah sangat penting untuk ditingkatkan. Telah di hitung dan diketahui hasil pengumpulan kuesioner menyatakan bahwa tingkat fasilitas dan tingkat layanan yang diberikan oleh karyawan SPBU itu kurang baik bagi konsumen. Setelah ada uji validitas dan regresi tingkat fasilitas lah yang kurang baik. Dan harus ditingkatkan oleh karyawan SPBU maka dari itu karyawan harus melakukan perubahan peningkatan kinerja yang lebih baik pada SPBU seluruh cabang yogyakarta, baik meningkatkan SDM, misalnya menambahkan pelatihan karyawan yang bekerjaagar kepuasan konsumen yang melakukan pelayanan jasa tersebut merasa puas. Selain itu komponen yang dianggap tidak perlu, sebaiknya tidak dijadikan fokus utama meningkatkan pelayanan diSPBU seluruh cabang yogyakarta.

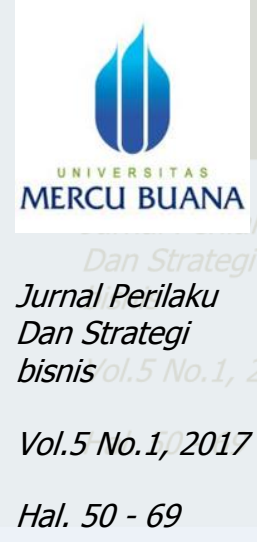

Hal. $50-69$
\end{abstract}

JPSB Vol.5 No.1, 2017 


\section{Kata Kunci : Tingkat kepuasan, Kualitas Pelayanan, SPBU seluruh cabang yogyakarta}

\section{PENDAHULUAN}

Pertamina sebuah perusahaan pertambangan minyak dan gas bumi Negara milik Negara Indonesia yang berbasis di Jakarta, pertamina juga perusahaan satu satunya milik Indonesia yang ada diJakarta, pertamina juga memiliki dua cadangan gas dan perusahan petrokimia. Produk pertamina meliputi berbagai macam bahan bakar, bahan kimia, aditif dan produk produk lain. Pertamina adalah salah satu perusahaan yang menyediakan minyak minyak yang beredar diwilayah seluruh indonesia pertamina juga mempermudahkan konsumen untuk mengunakan bahan bakar minyak (BBM) seperti solar, premiun, partamak dan lain lain yang ada diSPBU. Pertamina mendirikan PT Pertagas pada tanggal 23 Februari 2007, dan itu menjadi PT. Pertamina Gas pada tahun 2008. Perusahaan melakukan transportasi gas, perdagangan dan pengelolahan. Dalam bisnis transmisi gas, Pertamina memiliki jaringan pipa gas dengan total volume 34.000 km-inci di Sumatera Utara, Sumatera Tengah, Sumatera Selatan, Jawa Barat, Jawa Timur, dan Kalimantan Timur

Pada tahun 1960 kongres memberlakukan kebijakan bahwa pertambangan gas dan minyak tanah di Indonesia hanya di izinkan untuk Negara, melalui perusahaan Negara yang dikelola oleh pertamina pada tahun 1961. pertamina juga bertanggu jawab atas atministrasi pengndalian eksplorasi dan produksi. Kebijakan tersebut tidak berlangsung lama kerna kesepakatan antar Negara asing yang menegaskan bahwa secara bertahap perbaikan minyak memperoduksi. pada tahun 1974 kenaikan harga minyak yang dihasilkan pendapatan sebesar 4,2 miliar pada tahun itu setara produk domestic sebagai pendapatan Negara Pada tahun 1973, kemampuan pemerintah untuk meminjam uang dari luar negeri dibatasi, dan Pertamina tidak lagi memberikan pendapatan kepada negara. Sebaliknya, perusahaan besar ternyata tidak menghasilkan uang, tetapi kompilasi kerugian eksponensial besar.

Pada bulan Februari 1975, Pertamina tidak bisa lagi membayar kreditor Amerika dan Kanada Sebuah penyelidikan diikuti, yang mengungkapkan lebih dari US \$ 10 miliar utang, salah urus, dan korupsi dalam perusahaan. Utang ini setara dengan sekitar tiga puluh persen dari GNP Indonesia pada saat itu. Lain menawarkan sosok utang \$15 milyar Sebuah penyelidikan publik merusak reputasi elit nasional baik di kalangan orang Indonesia dan orang asing, Pengamat hak asasi manusia telah lama menyatakan keprihatinan tentang permusuhan Indonesia untuk serikat buruh. Menurut Monitor Multinasional: 
"Pada tahun 1985, pemerintah memerintahkan penembakan lebih dari 1.600 pekerja di Pertamina dan perusahaan minyak asing, pengisian bahwa mereka telah menjadi anggota Partai Komunis Indonesia, yang telah dilarang 19 tahun sebelumnya ketika Soeharto mengambil alih kekuasaan. Dalam penelitian ini penulis perlu mengetahui dan mencari permasalahan yang ada di SPBU untuk mencari tingkat kualitas dan pelayanan yang ada di SPBU maka penulis mewawancarai langsung ke beberapa konsumen yang mengunakan layanan SPBU seperti.

Bapak Joko seorang pengusaha lele usia 38 tahun mengatakan " pelayanan yang ada di SPBU yang ada diyogyakarta saat ini lumayan memuaskan bagi konsumen terutama dalam pelayanan yang diberikan oleh pertamina". Menurut saudara Boyan seorang karyawan warnet dia menceritakan "ada sebagian SPBU yang ada didaerah yogyakarta dalam pelayanan kurang maksimal kerna kurang senyumnya dan kurang ramahnya kepada konsumen dalam melayani pada saat melakukan pengisian bahan bakar minyak (BBM)". Menurut Wulandari adalah seorang mahasiswi mercu buana " pelayanan di SPBU pada saat pembelian (BBM) pelayananya kurang memuaskan seperti kurang senyum kepada konsumen". Menurut Ria seorang mahasiswi mercu buana "kalau dalam pelayanan pembelian uang kembali yang kurang. Misalnya habisnya 13.700 kita membayarnya dengan uang 20.000 maka kembalinya hanya 6.000 menurut saya itu termasuk korupsi". Menurut Wulan "dalam pelayanan masih ada karyawan yang kurang maksimal dalam bekerja. Misalanya pengisian BBM masih ada yang kura rapi seperti bensin yang dimasukan ke sepeda motor masih ada yang be ceceran keluar". Menurut saudari Sri "setiap SPBU harus ditingkatkan dalam tempat beristrahat untuk pengguna / pembeli yang sedang dalam perjalanan jauh".

Dalam hasil wawancara langsung kepada konsumen maka saya simpulkan bahwa dalam pelayanan yang diberikan oleh karyawan SPBU lumayan memuaskan bagi konsumen, namun beberapa konsumen merasa di rugikan dan kurang puas dalam pelayanan yang ada diSPBU. Konsumen menemukan permasalah pelayanan yang ada diSPBU yang perlu ditingkatkan oleh pihak pertamina saat ini seperti senyuman kepada konsumen, uang pengembalian dalam bembayaran yang kurang, bensin yang bececeran, tempat istrahat bagi pejalan jauh, fasilitas ATM yang kurang diperhatikan dalam mengambil uang tunai, antrian yang panjang, berseragam yang kurang rapi, fasilitas tempat ibadah seperti sarung dan mukenah yang tidak disiapkan dan fasilitas minimarket yang kurang lengkap. Dari permasalahan tadi maka pihak pertamina harus 
meningkatkan kualitas dan pelayanan yang ada dipertamina agar konsumen merasa puas saat melakukan / mengisi bahan bakar minyak (BBM). Melihat latar belakang tersebut diatas yaitu, peranan kualitas pelayanan terhadap sikap konsumen, maka untuk mengetahui kualitas pelayanan yang mana masih perlu ditingkatkan maka penulis mengadakan penelitian dengan judul eksplorasi evaluasi kepuasan pelayanan konsumen terhadap kualitas jasa pada pertamina cabang Yogyakarta.

\section{PENELITIAN TERDAHULU}

Penelitian Esti Wahyu Pratiwi ( 2013) dengan judul "pengaruh kualitas layanan SPBU pasti pas kepuasan konsumen dikota malang ( studi pada SPBU pasti pas jalan panglima sudurman kota malang)" populasi dalam penelitian ini adalah pelanggan SPBU pasti pas dikota malang dijalan panglima sudirman peneliti ini adalah mengunakan fasilitas SPBU yang siknifikat terhadap kepuasan konsumen terhadap pelayanan SPBU. Peneliti Suhardi (2008) dengan judul pengaruh penerapan pertamina way terhadap kepuasan layanan dalam rangka meningkatkan loyaritas variabel variabel yang diteliti pada penelitian ini adalah relationsif dan loyalitas pelanggan dari kesimpulan ini dapat disimpulkan bahwa loyalitas pelanggan merupakan dorongan perilaku yang melakukan pembelian secara berulang ulang untuk membangun kesetian pelanggan.

Peneliti Teiasih Endah Lestari (2011) dengan judul "kepuasan pelanggan terhadap pelayanan SPBU pasti pas di perumnas bekasi timur"'variabel variable yang digunakan adalah pada penelitian ini terdapat kesimpulan bahwa peneliti mengukur dan mengelola kualitas layanan yang ada di SPBU bekasi timur terhadap layanan yang ada di pertamina.

Peneliti Aryo Gesang Kapuji Rahadian (2004) dengan judul " analisis pengaruh layanan jasa terhadap kepuasan pelanggan pada PT, PERTAMINA UPMS" variable variable yang dugunakan adalah loyalitas pelanggan terhadap konsumen merupakan dorongan secara berulang ulang untuk membangun kualitas layanan terhadap karyawan yang bekerja di salah satu pombensin.

Peneliti Vaggy Harsa Volanda (2013) dengan judul kasus evaluasi layanan pertamina pastipas di SPBU arpin ahmad pekanbaru variable variable yang digunakan adalah tangible, reliability, responsiveness, asuranse dan empati dari penelitian ini pertamina adalah salah satu penyaluran BBM kepada masyarakat , pertamina juga menerapkan strategi yang dinamakan program pertamina way untuk meningkatkan standar pelayanan diSPBU. Peneliti Mayang Septa Mardiana (2013) dengan judul analisis pengaruh kualitas layanan dan pasiltas terhadap kepuasan pelanggan variabel variabel yang diteliti adalah bauran ritel, dari lokasi 
produk nilai karyawan, dan komunikasi yang signifikat secara silmulta kepuasan pembeli terhadap konsumen.

Peneliti Erlando (2012) dengan judul " analisis pengaruh layanan prima servie excellence terhadap kepuasan pelanggan pada SPBU pertamina. Variable variable yang diteliti adalah untuk mempengaruhi data perimer yaitu data yang diperoleh pengamatan (observations), wawancara (interviu), kuesioner (quastionare), penelitian kepustakaan (library researeh) peneliti yang dimaksud untuk mencari atau memperoleh data sekunder yang bersifat teoritas kepustakaan. Peneliti Deny Afika Nindani (2012) dengan judul "analisis pengaruh layanan prima (service excellence) terhadap kepuasan konsumen" variable variable yang digunakan depinisi oprasioonal variable pengukuran kualitas layanan tehadap kepuasan konsumen yang mengunakan pelayanan jasa.

Peneliti Indah Agustin (2011) dengan judul sikap pelanggan terhadap layanan costumer care (stadi deskrrpttif sikap pelanggan PT. pertamina (persero) area jatim dan Surabaya) dari judul tersebut peneliti mencari permasalah dalam pelayanan pertamina kepada konsumen terhadap kostemer area yang ada dijatim dan Surabaya. Peneliti Mudjiharto (2009) dengan judul "evaluasi kinerja system informasi pelayanan penjualan produk pertaminan persero unit pemasaran" Memanfaatkan Sistem Informasi Pelayanan Penjualan Produk (SIPPP) guna menjalankan proses bisnis penjualan produk. Sistem ini terdiri dari beberapa sistem yang saling memiliki antar muka satu sama lain. Karena menyangkut proses pelayanan penjualan BBM dan Non-BBM yang menyangkut kehidupan masyarakat serta dengan nilai uang yang besar, sistem tersebut menjadi sangat penting.

Dari beberapa penelitian yang telah tercantum diatas bahwa beberapa peneliti tentang kualitas layanan yang ada diSPBU peneliti mendapatkan kekurangan pelayanan yang diterapkan oleh karyawan kepada konsumen, karyawan pertamina kurang meningkatkan layanan terhadap konsumen yang melakukan pasilitas yang ada dipertamina.

\section{RUMUSAN MASALAH}

Dalam kegiatan bisnis ini pelayanan jasa harus di tingkatkan dalam melayani konsumen apabila bisnis jasa yang kurang memuaskan maka konsumen akan merasa kurang puas dalam pelayanan / fasilitas yang disiapkan oleh pembisnis jasa. Melihat rumusan tersebut maka dapat dirumuskan.

1. Bagaimana sikap konsumen dalam dimensi kualitas pelayanan secara menyeluruh yang diberikan oleh karyawan SPBU seluruh cabang yogyakarta? 
2. Berdasarkan sikap konsumen dimensi pelayanan manakah yang perlu ditingkatkan?

\section{TEORI DAN PENGEMBANGAN HIPOTESIS}

Perilaku konsumen adalah proses dan aktivitas ketika seseorang berhubungan dengan pencarian, pemilihan, pembelian, penggunaan, serta pengevaluasian produk dan jasa demi memenuhi kebutuhan dan keinginan. Perilaku konsumen merupakan hal-hal yang mendasari konsumen untuk membuat keputusan pembelian. Untuk barang berharga jual rendah (low-involvement) proses pengambilan keputusan dilakukan dengan mudah, sedangkan untuk barang berharga jual tinggi (high-involvement) proses pengambilan keputusan dilakukan dengan pertimbangan yang matang. Pemasaran adalah proses penyusunan komunikasi terpadu yang bertujuan untuk memberikan informasi mengenai barang atau jasa dalam kaitannya dengan memuaskan kebutuhan dan keinginan manusia.

Pemasaran dimulai dengan pemenuhan kebutuhan manusia yang kemudian bertumbuh menjadi keinginan manusia. Contohnya, seorang manusia membutuhkan air dalam memenuhi kebutuhan dahaganya. Jika ada segelas air maka kebutuhan dahaganya akan terpenuhi. Namun manusia tidak hanya ingin memenuhi kebutuhannya namun juga ingin memenuhi keinginannya yaitu misalnya segelas air merek Aqua yang bersih dan mudah dibawa. Maka manusia ini memilih Aqua botol yang sesuai dengan kebutuhan dalam dahaga dan sesuai dengan keinginannya yang juga mudah dibawa. Proses dalam pemenuhan kebutuhan dan keinginan manusia inilah yang menjadi konsep pemasaran. Mulai dari pemenuhan produk (product), penetapan harga (price), pengiriman barang (place), dan mempromosikan barang (promotion). Seseorang yang bekerja dibidang pemasaran disebut pemasar. Pemasar ini sebaiknya memiliki pengetahuan dalam konsep dan prinsip pemasaran agar kegiatan pemasaran dapat tercapai sesuai dengan kebutuhan dan keinginan manusia terutama pihak konsumen yang dituju.

Berikut ini adalah yang perlu diperhatiakan dalam pemasaran yaitu, tempat yang strategis, produk yang bermutu, harga yang kompetitif dan promosi yang gencar. Dari apa yang sudah dibahas di atas ada beberapa hal yang dapat disimpulkan, bahwa pembuatan produk atau jasa yang diinginkan oleh konsumen harus menjadi fokus kegiatan operasional maupun perencanaan suatu perusahaan. Pemasaran yang berkesinambungan harus adanya koordinasi yang baik dengan berbagai departemen (tidak hanya dibagian pemasaran saja), sehingga dapat 
menciptakan sinergi di dalam upaya melakukan kegiatan pemasaran. Pemasaran adalah suatu system keseluruhan dari kegiatan-kegiatan usaha yang ditujukan untuk merencakan, menentukan harga, mempromosikan dan untuk mendistribusikan barang dan jasa yang dapat memuaskan kebutuhan baik kepada pembeli yang ada maupun pembeli yang potensial (Wlliam J. Stanton, Fundamentalis of Marketing, 1978).

Pengetian Jasa adalah semua tindakan atau kegiatan yang dapat tawarkan oleh satu pihak kepada pihak lainnya yang tidak berwujud dan tidak menyebabkan kepemilikan apapun. Beberapa hal berikut merupakan karakteristik dari jasa, yaitu intangible atau tidak terlihat. Tidak terpisahkan antara jasa yang disediakan dengan penyedia jasa. Kemudian bervariasi, dalam hal ini adalah standar nilai dari suatu jasa terhadap pelanggan adalah berbeda-beda. Dan yang terakhir adalah Mudah lenyap, karena jasa hanya ada ketika proses transaksi antara penyedia jasa dan pelanggan berlangsung. Setelah itu jasa akan hilang. Berbeda halnya dengan produk yang dapat dimiliki setelah transaksi terjadi. Kualitas jasa atau layanan merupakan tingkat kesenjangan antara harapan atau keinginan pelanggan dengan persepsi atau performansi yang telah mereka rasakan.

Produk jasa memiliki karakteristik yang berbeda dengan barang, karakteristiknya sebagai berikut:

a) Intangibility ( tidak berwujud )Jasa tidak dapat dilihat atau dicium sebelum jasa itu dibeli. Nilai penting dari hal ini adalah nilai tidak berwujud yang dialami konsumen dalam bentuk kenikmatan, kepuasan, atau rasa aman.

b) Inseparability, umumnya pada aktivitas jasa proses produksi dan konsumsi terjadi secara bersamaan, dalam arti konsumen terlibat dalam produksi implikasinya kontak dan interaksi menjadi sangat penting.

c) Heterogeinity, standarisasi sulit dilakukan karena sangat tergantung kepada sumberdaya manusia yang terlibat, sehingga kualitas sulit dikendalikan. Masalah yang berkaitam dengan karakteristik heterogeneity, adalah sangat sulit melakukan standarisasi dan pengendalian kualitas jasa.

d) Perishabillity, jasa tidak mengenal persediaan atau penyimpanan dari produk yang telah dihasilkan.

e) Lack of ownership, pelanggan tidak memiliki jasa pada pembelian jasa pelanggan hanya memiliki akses personal atas suatu jasa untuk jangka waktu yang terbatas.

Berdasarkan karakteristik jasa diatas maka usaha yang saya pilih termasuk karakteristik Inseparability, umumnya pada aktivitas jasa proses produksi dan 
konsumsi terjadi secara bersamaan, dalam arti konsumen terlibat dalam produksi implikasinya kontak dan interaksi menjadi sangat penting.

Pengertian secara umum mengenai kepuasan atau ketidakpuasan konsumen merupakan hasil dari adanya perbedaan - perbedaan antara harapan konsumen dengan kinerja yang dirasakan oleh konsumen tersebut.Dari beragam definisi kepuasan konsumen yang telah diteliti dan didefinisikan oleh para ahli pemasaran, dapat disimpulkan bahwa kepuasan konsumen merupakan suatu tanggapan perilaku konsumen berupa evaluasi purna beli terhadap suatu barang atau jasa yang dirasakannya (kinerja produk) dibandingkan dengan harapan konsumen. Kepuasan konsumen ini sangat tergantung pada persepsi dan harapan konsumen itu sendiri. Faktor-faktor yang mempengaruhi persepsi dan harapan konsumen ketika melakukan pembelian suatu barang atau jasa adalah kebutuhan dan keinginan yang dirasakan oleh konsumen tersebut pada saat melakukan pembelian suatu barang atau jasa, pengalaman masa lalu ketika mengkonsumsi barang atau jasa tersebut serta pengalaman teman-teman yang telah mengkonsumsi barang atau jasa tersebut dan periklanan. Sedangkan kepuasan menurut Kotler dan Armstrong (2001) Kepuasan konsumen adalah sejauh mana anggapan kinerja produk memenuhi harapan pembeli. Bila kinerja produk lebih rendah ketimbang harapan pelanggan, maka pembelinya merasa puas atau amat gembira. Menurut Zeithaml dan Bitner (2000) definisi kepuasan adalah : Respon atau tanggapan konsumen mengenai pemenuhan kebutuhan. Kepuasan merupakan penilaian mengenai ciri atau keistimewaan produk atau jasa, atau produk itu sendiri, yang menyediakan tingkat kesenangan konsumen berkaitan dengan pemenuhan kebutuhan konsumsi konsumen.

Kualitas merupakan suatu kondisi dinamis yang berpengaruh dengan produk, jasa, manusia, proses dan lingkungan yang memenuhi atau melebihi harapan (Tjiptono, 2001). Sehingga definisi kualitas pelayanan dapat diartikan sebagai upaya pemenuhan kebutuhan dan keinginan konsumen serta ketepatan penyampaiannya dalam mengimbangi harapan konsumen (Tjiptono, 2007). Kualitas pelayanan (service quality) dapat diketahui dengan cara membandingkan persepsi para konsumen atas pelayanan yang nyata-nyata mereka terima / peroleh dengan pelayanan yang sesungguhnya mereka harapkan / inginkan terhadap atribut-atribut pelayanan suatu perusahaan. Jika jasa yang diterima atau dirasakan (perceived service) sesuai dengan yang diharapkan, maka kualitas pelayanan dipersepsikan baik dan memuaskan, jika jasa yang diterima melampaui harapan konsumen, maka kualitas pelayanan dipersepsikan sangat baik dan berkualitas.Sebaliknya jika jasa yang diterima 
lebih rendah dari pada yang diharapkan, maka kualitas pelayanan dipersepsikan buruk. Menurut Kotler (2002) definisi pelayanan adalah setiap tindakan atau kegiatan yang dapat ditawarkan oleh suatu pihak kepada pihak lain, yang pada dasarnya tidak berwujud dan tidak mengakibatkan kepemilikan apapun. Produksinya dapat dikaitkan atau tidak dikaitkan pada satu produk fisik.

Pelayanan merupakan perilaku produsen dalam rangka memenuhi kebutuhan dan keinginan konsumen demi tercapainya kepuasan pada konsumen itu sendiri. Kotler juga mengatakan bahwa perilaku tersebut dapat terjadi pada saat, sebelum dan sesudah terjadinya transaksi. Pada umumnya pelayanan yang bertaraf tinggi akan menghasilkan kepuasan yang tinggi serta pembelian ulang yang lebih sering. Kata kualitas mengandung banyak definisi dan makna, orang yang berbeda akan mengartikannya secara berlainan tetapi dari beberapa definisi yang dapat kita jumpai memiliki beberapa kesamaan walaupun hanya cara penyampaiannya saja biasanya terdapat pada elemen yaitu, kualitas meliputi usaha memenuhi atau melebihkan harapan pelanggan, kualitas mencakup produk, jasa, manusia, proses dan lingkungan serta kualitas merupakan kondisi yang selalu berubah.

\section{METODE PENELITIAN}

Penelitian ini dilakukan didaerah istimewa Yogyakarta pada pertamina seluruh Cabang Yogyakarta yang ada diSPBU pertamina.

Defenisi operasional variable dalam penelitian ini adalah sebagai berikut:

1. Kepuasan adalah tingkat perasaan seorang konsumen dengan membandingkan antara kinerja (hasil yang dirasakan) dengan hasil yang diharapkan. Seperti senyuman kepada konsumen, uang pengembalian dalam pembayaran yang kurang, bensin yang bececeran, tempat istrahat bagi pejalan jauh, fasilitas ATM yang harus ditingkatkan dalam pengambilan uang tunai, antrian yang panjang, berseragam yang kurang rapi, fasilitas ibadah yang kurang diperhatikan seperti sarung dan mukenah yang tidak disiapkan dan fasilitas minimarket yang kurang lengkap. Tingkat kepuasan yang ada di SPBU yang harus ditingkatkan dari permasalahan yang dicantumkan diatas.

2. Kualitas jasa adalah ukuran seberapa bagusnya tingkat layanan yang diberiakan mampu sesuai dengan ekspektasi pelanggaran. Dalam penelitian ini kualitas jasa meliputi: fasilitas, Variable ini meliputi fasilitas yang ada diSPBU pertamian yang perlu ditingkatkan seperti tempat istrahat bagi pejalan jauh, fasilitas ATM yang kurang diperhatikan dalam pengambilan uang tunai, fasilitas tempat ibadah yang kurang diperhatikan seperti sarung dan mukenah yang tidak disiapkan, dan fasilitas minimarket yang kurang 
lengkap. Yaitu besar harapan yang harus diinginkan oleh Pertamina pada saat konsumen berada atau saat melakukan pengisian di SPBU. Intangible Variable meliputi dalam pelayanan yang harus ditingkatkan atau harus di perbaiki oleh pihak pertamina. Seperti senyuman kepada konsumen, anterian terlalu panjang dan lain lain. Tangible Variabel meliputi pelayanan yang kurang memuaskan terhadap konsumen seperti uang pengembalian dalam pembayaran yang kurang, bensin yang bececeran, dan berseragam yang kurang rapi. Besar harapan konsumen dalam pelayanan terhadap konsumen yang mengunakan jasa pertamina agar pihak pertamina meningkatkan layanan yang baik terhadap konsumen.

\section{POPULASI DAN SAMPEL}

Populasi adalah keseluruhan karakteristik atau sifat yang diinginkan oleh subjek atau objek yang diteliti (sugiono : 2008). Polupasi pada penelitian ini adalah seluruh karyawan pertamina cabang yogyakarta, baik karyawan funding maupun karyawan lending. Sampel adalah bagian dari popuasi yang dianggap dapat mewakili populasi dalam penelitian. Sempel ini merupakan bagian dari populasi yang kriterianya hendak di duga . taknik sampling dalam penelitian ini adalah purosive random sampling, yakni taknik sampling dengan mempertimbangkan kriteria tertentu. Responden (subjek) yang dipilih secara sengaja dengan karakteristik tertentu yang diyakini depresentatif terhadap populasi penelitian. Penentuan jumlah sempel dalam penelitian ini mengunakan rumusan slovin ( skaran :1992). Berdasarkan rumus yang digunakan maka jumlah sampel dalam penelitian ini sebanyak 200 orang.

\section{METODE PENGUMPULAN DATA}

Dalam penelitian ini metode pengumpulan data yang digunakan adalah koesioner, observasi dan dokumentasi. Kuesioner yaitu dengan memberikan daftar pertanyaan yang telah dibuat dan ditentukan oleh peneliti responden ,yaitu konsumen telah mengunakan jasa SPBU yang ada di wilayah yogyakarta. Kuesioner ini digunakan untuk mendapatkan bahan bahan tertulis untuk mendukung penelitian ini. Observasi yaitu penelitian ini dilakukan pengamatan secara langsung terhadap kegiatan objek yang diteliti, observasi pada peneliti ini dilakaukan diSPBU Cabang Yogyakarta. Dokumentasi adalah catatan peristiwa yang sudah berlalu, dokumen bisa berbentuk tertulis, gamabar atau karya karya dokumentasi dari seseorang, dalam penelitian ini mengunakan dokumentasi 
untuk memperoleh data tentag penerapan bauran pemasaran pada Pertamina cabanag Yogyakarta.

\section{METODE ANALISIS DATA}

Dalam penelitian ini mengunakan metode analaisis deskriptif. Metode analisis deskriftif digunakan untuk membentu mengidentifikasi dan pemaparan terhadap unsur unsur yang menjadi fokus dalam penelitian. Dalam penelitian ini metode analisis deskriptif mengunakan alat mean aritmetic yaitu hasil bagi dari jumlah semua nilai dengan banyaknya nilai. Dan metode analaisis tingkat harapan kinerja yang digunakan untuk mencari tingkat kepuasan konsumen mengunakan diagram kartesius. Setelah dilakukan beberapa pengujian arimatic maka selanjutnya data di analisis dengan menggunakan regresi linear berganda.

\section{HASIL PENELITIAN}

Pertamina (dahulu bernama Perusahaan Pertambangan Minyak dan Gas Bumi Negara) adalah sebuah BUMN yang bertugas mengelola penambangan minyak dan gas bumi di Indonesia. Pertamina pernah mempunyai monopoli pendirian SPBU di Indonesia, namun monopoli tersebut telah dihapuskan pemerintah pada tahun 2001. Pertamina adalah hasil gabungan dari perusahaan Pertamin dengan Permina yang didirikan pada tanggal 10 Desember 1957.Penggabungan ini terjadi pada 1968 Direktur utama (Dirut) yang menjabat dari 2009 hingga 2014 adalah Karen Agustiawan yang dilantik oleh Menneg BUMN Syofan Djalil pada 5 Februari 2009 menggantikan Dirut yang lama Ari Hernanto Soemarno. Pelantikan Karen Agustiawan ini mencatat sejarah penting karena ia menjadi wanita pertama yang berhasil menduduki posisi puncak di perusahaan BUMN terbesar milik Indonesia itu. KarenAaAgustiawan mengundurkan diri sebagai Dirut pada 1 Oktober 2014 dan menjadi dosen guru besar di Harvard University, Boston, Amerika Serikat.

Selanjutnya pada 28 November 2014, Presiden Joko Widodo memilih Dwi Soetjipto sebagai Direktur Utama PT Pertamina (Persero). Kegiatan usaha Pertamina Hulu meliputi eksplorasi dan produksi minyak, gas, dan panas bumi. Untuk kegiatan eksplorasi dan produksi minyak dan gas dilakukan di beberapa wilayah Indonesia maupun di luar negeri. Pengusahaan di dalam negeri dikerjakan oleh Pertamina Hulu dan melalui kerjasama dengan mitra sedangkan untuk pengusahaan di luar negeri dilakukan melalui aliansi strategis bersama dengan mitra. Berbeda dengan kegiatan usaha di bidang minyak dan gas bumi, kegiatan eksplorasi dan produksi panas bumi masih dilakukan di dalam negeri.

JPSB Vol.5 No.1, 2017 
Untuk mendukung kegiatan intinya, Pertamina Hulu juga memiliki usaha dibidang pemboran minyak dan gas.

Bidang Pengolahan mempunyai 7 unit kilang dengan kapasitas total 1.041,20 Ribu Barrel. Beberapa kilang minyak terintegrasi dengan kilang Petrokimia dan memproduksi NBBM, Ketujuh Kilang minyak tersebut terdiri dari :

1. Unit Pengolahan I di Pangkalan Brandan - Sumatera Utara (ditutup pada Januari 2007) dan bergabung dengan Unit Pengolahan II Dumai pada tahun 2010.

2. Unit Pengolahan II di Dumai - Riau.

3. Unit Pengolahan III di Plaju-Sei Gerong Palembang - Sumatera Selatan.

4. Unit Pengolahan IV di Cilacap - Jawa Tengah.

5. Unit Pengolahan V di Balikpapan - Kalimantan Timur.

6. Unit Pengolahan V di Balikpapan - Kalimantan Timur.

7. Unit Pengolahan VII di Sorong - Papua

Dalam hal pengembangan usaha, Pertamina telah mulai mengembangkan usahanya baik di dalam dan luar negeri melalui aliansi strategis dengan mitra. Pertamina juga memiliki usaha yang prospektif di bidang jasa pemboran minyak dan gas melalui Pertamina Drilling Service (PDS) yang memiliki 26 unit rig pemboran serta anak perusahaan PT Usayana yang memiliki 7 rig pemboran. Dalam kegiatan transmisi gas, Pertamina memiliki jaringan pipa gas dengan panjang total $3800 \mathrm{~km}$ dan 64 stasiun kompresor.

Pertamina juga mempunyai bermacam macam peroduk yang disiapkan oleh perusahan, adapaun produk yang disiapkan oleh pertamina adalah:

1. BioPertamax, Pertamax

2. Pertamax Plus

3. BioPremium, Premium

4. Solar, Bio Solar, Pertamina DEX

Disamping itu pertamina juga menyediakan bahan tambahan seperti minyak lumas mesin kendaraan dengan bahan dasar semi synthetic.

1. Prima XP SAE $20 \mathrm{~W}$ - 50 adalah pelumas produksi Pertamina untuk mesin bensin.

2. Mesran Super SAE $20 \mathrm{~W}-50$ adalah pelumas mesin bensin.

3. Mesrania $2 \mathrm{~T}$ Super- $\mathrm{X}$ adalah pelumas mesin bensin dua langkah yang berpendingin air seperti mesin tempel atau speed boat.

Perusahan adalah cabang yang ada di seluruh indonesia, dan kantor pusat pertamina adalah Kantor Pusat Pertamina di Jalan Medan Merdeka Timur, Jakarta. 
Adapun cabang cabang di bawah ini:

1. PT Pertamina EP - Usaha hulu di bidang minyak dan gas bumi meliputi: eksplorasi, eksploitasi serta penjualan produksi minyak dan gas bumi hasil kegiatan eksploitasi.

2. PT Pertamina Geothermal Energy - Pengelolaan dan pengembangan sumber daya panas bumi meliputi kegiatan eksplorasi \& ksploitasi, produksi uap dan pembangkitan listrik dan jasa konsultasi, konstruksi, operasi dan pemeliharaan serta pengembangan teknologi di bidang panas bumi.

3. PT Pertagas - Niaga, transportasi distribusi, pemrosesan dan bisnis lainnya yang terkait dengan gas alam dan produk turunannya.

4. PT Pertamina Hulu Energi - Pengelolaan usaha sektor hulu minyak \& gas bumi serta energi baik dalam maupun luar negeri serta kegiatan usaha yang terkait dan atau menunjang kegiatan usaha di bidang minyak \& gas bumi.

5. PT Pertamina EP Cepu - Eksplorasi, eksploitasi dan produksi di Blok Cepu

6. PT Pertamina Drilling Services Indonesia - Pengelolaan dan pengembangan sumber daya jasa drilling meliputi eksplorasi dan eksploitasi baik migas maupun panas bumi.

7. PT Nusantara Regas - Pengelolaan dan pengembangan Fasilitas Storage and Regasification Terminal (FSRT) termasuk pembelian LNG dan pemasaran hasil pengelolaan FSRT.

8. PT Pertamina Patra Niaga - Jasa teknologi, jasa perdagangan Non BBM serta industri di bidang pertambangan minyak dan gas bumi.

9. PT Pertamina Trans Kontinental - Jasa pperasi [erkapalan meliputi supply vessels, tug boat, cargo vessels, keagenan dan pengelolaan dermaga KABIL di Pulau Batam.

10. Pertamina Energy Trading Limited (PETRAL)- Niaga minyak mentah dan produk kilang lokasi usaha di Singapura.

11. PT Pertamina Retail - Retail SPBU, perdagangan BBM dan jasa pengangkutan BBM.

12. PT Tugu Pratama Indonesia - Jasa asuransi kerugian yang berkaitan dengan operasional industri migas dan marine hull.

13. PT Pertamina Dana Ventura - Kegiatan modal ventura 
Tabel 1. Sampel

Sampel dan Tingkat pengambilan kuesioner

\begin{tabular}{lc}
\hline \multicolumn{1}{c}{ Keterangan } & Jumlah \\
\hline Kuesioner yang dikirim & 200 \\
\hline Kuesioner yang tidak kembali & 0 \\
\hline Jumlah kuesioner yang dianalisis & 200 \\
\hline Kuesioner yang diisi mahasiswa & 200 \\
\hline Kuesioner yang diisi masyarakat & 0 \\
\hline Tingkat pengembalian & $100 \%$ \\
\hline Tingkat pengambalian yang dapat diolah & $100 \%$ \\
200/100x100\% & 200 \\
\hline Total
\end{tabular}

Sumber : Data primer diolah dari lampiaran

Karakteristik responden yang diteliti yaitu jenis kelamin, kampus, kelas, usia, pendapatan perbulan dan pekerjaaan. secara rinci karakteristik responden dari konsumen yang mengunakan layanan SPBU pertamina cabang yogyakarta dapat dijelaskan sebagai berikut:

1. Karakteristik jenis kelamin

Berdasarkan jenis kelamin, responden dalam penelitian ini diklasifikasikan sebagai berikut:

Tabel 2. Karakteristik Jenis Kelamin

Karakteristik menurut jenis kelamin

\begin{tabular}{llll}
\hline No & Jenis kelamin & Jumlah & Persentase \\
\hline $\mathbf{1}$ & Laki laki & 107 & $53,5 \%$ \\
$\mathbf{2}$ & Perempuan & 93 & $46,5 \%$ \\
& Total & 200 & $100 \%$ \\
\hline
\end{tabular}

Sumber : data primer

Berdasarkan tabel 2 tersebut dapat disimpulkan bahwa dalam penelitian ini responden yang berjeniskelamin. Laki-laki mengisi kuesioner berjumlah 107 respoden/orang, sedangkan perempuan yang mengisi kuesioner berjumlah 93 responden/orang jadi total kuesioner yang di isi adalah berjumlah 200 responden.

2. Karakteristik menurut fakultas

Berdasarkan hasil kuesioner yang disebar kepada responden, peneliti menyebarkan kuesioner dikampus mercu buana yang ada di jalan wates km.10 peneliti menyebarkan ke fakultas - fakultas seperti Fakultas Ekonomi, Fkip, Psikologi, dan Agroteknologi. Berikut tabel jumlah kuesioner: 
Tabel 3. Karakteristik Fakultas

Karakteristik menurut fakultas

\begin{tabular}{llll}
\hline No & Fakultas & Jumlah & Persentase \\
\hline $\mathbf{1}$ & Ekonomi & 64 & $32 \%$ \\
$\mathbf{2}$ & Fkip & 28 & $14 \%$ \\
$\mathbf{3}$ & Psikologi & 54 & $27 \%$ \\
$\mathbf{4}$ & Agroteknologi & 54 & $27 \%$ \\
\hline & Total & 200 & $100 \%$ \\
\hline
\end{tabular}

Sumber : data perimer yang diolah dari lampiran kuesioner

Berdasarkan tabel 3 tersebut dapat disimpulkan bahwa menurut kuesioner yang diisi setiap fakultas berjumlah 200 orang yang ada di kampus satu seperti fakultas Ekonomi berjumlah 64 orang/responden, fakultas Fkip berjumlah 28 orang/responden, fakultas Psikologi berjumlah 54 orang/responden, fakultas Agroteknologi berjumlah 54 orang/responden. Jadi total kuesioner yang disebar kepada mahasiswa berjumlah 200 responden.

3. Karakteristik status kampus mahasiswa

Berdasarkan hasil kuesioner dalam penelitian ini peneliti menyebarkan kuesioner didua tempat yaitu kampus satu dan kampus dua sebagai berikut:

Tabel 4. Karakteristik Mahasiswa

Karakteristik status kampus mahasiswa

\begin{tabular}{llll}
\hline No & Kampus & Jumlah & Persentase \\
\hline $\mathbf{1}$ & Satu & 200 & $100 \%$ \\
$\mathbf{2}$ & Dua & 0 & $0 \%$ \\
& Total & 200 & $100 \%$ \\
\hline
\end{tabular}

Sumber : data perimer yang diolah dari lampiran kuesioner

Berdasarkan tabel 4 tersebut dapat disimpulkan bahwa responden yang mengisi kuesioner yang disebar dikampus satu berjumlah 200. Peneliti tidak menyebar dikampus dua kerena seluruh kuesioner telah diisi dikampus satu.

4. Karakteristik menurut usia

Berdasarkan hasil penyebaran kuesioner pada mahasiswa peneliti menghitung jumlah usia yang mengisi kuesioner sebagai berikut:

Tabel 5. Karakteristik Usia

\begin{tabular}{llll}
\multicolumn{4}{c}{ Karakteristik usia } \\
\hline No & Usia & Jumlah & Persentase \\
\hline $\mathbf{1}$ & $19-20$ tahun & 150 & $75,0 \%$ \\
$\mathbf{2}$ & $21-22$ tahun & 48 & $24,0 \%$ \\
$\mathbf{3}$ & $23-24$ tahun & 2 & $1,0 \%$ \\
$\mathbf{4}$ & $25-26$ tahun & 0 & $0 \%$ \\
$\mathbf{5}$ & $27-28$ tahun & 0 & $0 \%$ \\
& & 200 & $100 \%$ \\
\hline
\end{tabular}

Sumber : data perimer yang diolah dari lampiran kuesioner 
Berdasarkan hasil tabel 5 dapat terhitung jumlah usia mahasiswa yang mengisi kuesioner yang disebarkan oleh kuesioner. Menurut penghitungan jumlah usia 19-20 tahun yang mengisi kuesioner berjumlah 150 orang/responden, usia 21-22 tahun yang mengisi kuesioner berjumlah 48 orang/responden, dan sedangkan usia 23-24 tahun yang mengisi kuesioner berjumlah 2 orang/ responden.

Pengujian regresi berganda dilakukan untuk mendapatkan persamaan regresi berganda dari variable independen (kepuasan konsumen) dan dan variabel dependen (fasilitas, intangibel dan tangibel) yang diteliti.

Tabel 6. Model Regresi

Model persamaan regresi

Coefficient

\begin{tabular}{l|c|c|c}
\hline \multirow{2}{*}{ Model } & \multicolumn{2}{|c|}{ Unstandardizen Coeffieientas } & Standardizd \\
\cline { 2 - 4 } & $\mathrm{B}$ & Std.Error & Beta \\
\hline ( constant ) & 16.779 & 3.306 & \\
Fasilitas & .731 & .360 & .176 \\
Intangibel & .625 & .545 & .094 \\
Tangibel & .611 & .204 & .214 \\
\hline
\end{tabular}

Sumber : SPSS 19.0 for windows

\section{HASIL REGRESI LINIER BERGANDA}

Koefisien regresi menunjukan arah perubahan variabel independen terhadap variable dependen. Dari tabel diatas diperoleh hasil uji regresi berganda dimana dapat dibentuk model regresi sebagai berikut:

$Y=16.779+.731 X 1+.625 X 2+.611 X 3+e$

Dimana :

$Y=$ kepuasan konsumen

$\mathrm{X} 1$ = Fasilitas

$\mathrm{X} 2$ = Intangibel

X3 = Tangibel

$\mathrm{e}=$ Eror

Berdasarkan hasil persamaan regresi diatas yang yang telah diolah dapat dijelaskan sebagai berikut ini:

1. $Y=$ nilai kepuasan konsumen sebesar 16,779 merupakan nilai konstanta, artinya tampa ada pengaruh dari tiga variable independen atau pun faktor lain, nilai dari variable kinerja karyawan mempunyai nilai konstanta sebesar 16,779 .

2. $\mathrm{X} 1=$ nilai fasilitas sebesar 0,731 merupakan arti bahwa setiap terjadi peningkatan penilaiaan karyawan terhadap variable tingkat fasilitas sebesar 
satu satuan, maka kinerja karyawan meningkat sebesar 0,731 satuan atau sebesar $73,1 \%$

3. $\mathrm{X} 2=$ nilai intangible sebesar 0,625 artinya jika setiap terjadi peningkatan kaaryawan terhadap variable intanjible maka kinerja karyawan meningkat sebesar 0,625 satuan atau sebesar 0,625 \%

4. $\mathrm{X3}=$ nilai tangible sebesar 0,611 artinya jika setiap terjadi peningkatan karyawan terhadap variable tangible maka kinerja karyawan meningkat sebesar 0,611 satuanye sebesar 0,611\%

5. Secara keseluruhan dari hasil analisis regresi dapat diketahui bahwa variabel paling dominan mempengaruhi kepuasan konsumen adalah variabel fasilitas, sebesar 0,731 lebih besar dari nilai variabel intangible 0,625 lebih besar dari 0,611

\section{PEMBAHASAN}

Dari hasil penyebaran kuesioner peneliti dapat menjelaskan bahwa kepuasan konsumen yang mengunakan jasa SPBU yang di siapkan oleh pertamina tentang fasilitas yang disediakan oleh perusahaan adalah tentang pertanyaan fasilitas satu itu sangat penting untuk ditingkatkan dari hasil rata rata menjelskan bahwa tingkat keputusan konsumen menunjukan sangat penting untuk ditingkatkan dalam fasilitas yang disediakan oleh perusahaan pertamina kerna jumlah keseluruhan menujukan rata rata "penting" dari seluruh variabel fasilitas yang ada untuk ditingkatkan. Dalam penilaian kepuasan konsumen responden menjelaskan bahwa antara jumlah keseluruhan pertanyaan yang disiapkan oleh peneliti menunjukan bahwa konsumen merasa tidak baik dalam pelayanan yang disiapkan oleh karyawan SPBU.

Dari hasil penelitian dapat dijelaskan bahwa kepuasan konsumen terhadap variable variable Intangible seperti senyuman kepada konsumen dan antrian yang sanagt panjang penting untuk ditingkatkan. Dari hasil kuesioner itu sangat penting untuk ditingkatkan kerena konsumen yang melakukan pelayanan tersebut merasa kurang puas dalam pelayanan dari karyawan SPBU seperti variable variable Intangibel pada pertanyaan senyuman kepada konsumen itu sangat penting untuk ditingkatkan bagi konsumen, konsumen juga merasa kurang puas dalam pelayanan tersebut. Dalam penilaiaan kepuasan konsumen pertanyaan intanjibel senyuman kepada konsumen masuk kategori tidak baik dalam pelayaan yang diberikan karyawan, namun dari hasil regresi terdapat tidak sigifikan hal ini berarti variable variable intanjibel yaitu senyuman kepada konsumen dan anterian yang sangat panjang indikator tersebut masuk kategori 
masih jauh dari harapan konsumen, kerna konsumen dapat menilai langsung dari pelayanan karyawan. Dapat disimpulkan bahwa seluruh konsumen yang mengunakan pelayanan tersebut sangat kurang puas terhadap pelayanan karyawan yang tidak baik bagi konsumen. Harapan konsumen terhadap kinerja karyawan seperti pertanyaan ddalam variable variable haruas di tingkatkan agar konsumen merasa puas terhadap pelayanan yang diberikan oleh karyawan SPBU. Dari hasil penelitian dapat dijelaskan bahwa kepuasan konsumen terhadap variable variable tangibel seperti uang penegmbalina dalam pembayaran, bensin yang bececeran, berseragam yang kurang rapi, dapat dijelaskan bahwa dari hasil penghitungan rerata pertanyaan variable tangible masuk kategori cukup penting untuk ditingkatkan dalam variable variable intanjibel menurut kepuasan konsumen memasuki kategori tidak baik dalam pelayanan yang disediakan dan diberikan oleh karyawan SPBU. Namun dalam hasil uji regresi itu mendapat kategori signifikan hal ini tetapi dalam hasil uji validitas menurut pertanyaan berseragam yang kurang rapi menurut hasil uji validitas mendapat tidak valid setelah ada hasil uji validitas dari SPSS 19,0 for windows.

\section{KESIMPULAN}

Berdasarkan hasil penelitian yang dilakukan diambil kesimpulan sebagai berikut: Pada variable variable fasilitas dimana tingkat kualitas pelayanan jasa seperti tempat istrahat bagi pejalan jauh, dan fasilitas tempat ibadah seperti mukenah dan sarung yang belum disiapkan. Pada variable variable fasilitas satu dan tiga itu yang menjadi proiritas pertama setelah uji validitas, disini strategi yang perlu ditingkatkan oleh pertamina SPBU untuk meningkatkan dan menjadikan variable variable ini sebagai focus untuk meningkatka kinerja karyawan dan untuk meningkatkan pelayanan diseluruh SPBU cabag Yogyakarta. Pada variable variable intangible dimana tingkat kualitas pelayanana jasa seperti senyuman kepada konsumen dari variable intanjibel itu yang menjadi proiritas pertama setelah ada hasil uji validitas . disini strategi yang perlu ditingkatkan pelayanan sebagai focus utama meningkatkan pelayanan diseluruh SPBU cabang Yogyakarta.

Pada variable variable tangible dimensi tingkat pelayanan kualitas jasa seperti pengembalian uang dalam pembayaran yang kurang, bensin yang bececeran pada pertanyaan tersebut itu yang menjadi prioritas utama yang perlu ditingkatkan oleh seluruh cabang Yogyakarta. Setelah ada uji validitas dua pertanyaan tersebut yang harus ditingkatkan oleh karyawan bagi seluruh cabang 
spbu Yogyakarta itu yang menjadikan variable ini sebagi fokus yang harus ditingkatkan dalam peayanan jasa SPBU seluruh cabang Yogyakarta.

\section{SARAN PENELITIAN}

Berdasarkan kesimpulan penelitian ini, maka saran yang dapat diajukan dan ditingkatkan adalah peningkatan kinerja yang lebih baik pada SPBU seluruh cabang Yogyakarta. Baik peningkatan SDM, misalnya penambahan pelatihan untuk karyawan. Seperti fasilitas yang di siapkan, senyuman dan pelayanan yang baik. Selain itu untuk komponen yang dianggap tidak perlu, sebaiknya tidak dijadikan fokus utama meningkatkan pelayanan diseluruh SPBU cabang Yogyakarta.

\section{DAFTAR PUSTAKA}

Anwar,(2009) alat ukur validitas. Metodologi penelitian. Pustaka baru press

Aryo Gesang Kopuji Rahadian,(2004) " Analisis pengaruh layanan jasa terhadap kepuasan pelanggan pada PT.Pertamina UPMS ${ }^{\prime \prime \prime}$

Audita Nuvriasari,(2013) Riset pemasaran.

Deny Afika Nindani,(2011) " Analaisis pengaruh layanan prima (servise excelence) terhadap kepuasan konsumen" ${ }^{\prime \prime \prime}$

Djojosuroto kinayanti dan M.L.A Sumayati,(2004) komunikasi ekonomi: pranada media.

Erlando,(2012) " Analisis pengaruh layanan prima servie excellence terhadap kepuasan pelanggan pada SPBU pertamina.

Esti Wahyu Pratiwi,(2013) “u” pengaruh kualitas layanan SPBU pastivas kepuasan konsumen dikota magelang ( studi pada SPBU pastipas jalan panglima sudarman kota magelang)

Indari Agustian,(2011) ${ }^{\prime \prime \prime \prime}$ sikap pelanggan terhadap layanan costemer area (studi deskriftif sikap pelanggan PT.Pertamina (persero)area jatim dan surabaya)

Istijanto,(2009) aplikasi praktis riset pemasaran. Cara praktis meneliti konsumen dan pesaing Edisi revisi_(2)

Kotler dan Armstrong,(2001) kepuasan konsumen, pustaka baru press

Kotler,(2002) Pemasaran. Gramedia Pustaka utama

Mayang Septa Mardana,(2013) " Analisis pengaruh kualitas layanan dan fasilitas terhadap kepuasan pelanggan"'

Mudhiharto,(2009) "'Evaluasi kinerja system informasi pelayanan penjualan produk pertamina unit pemasaran" 
Ronald E.Walpole,(2011) Pengantar Statistik, Edisi Ke_3 : Gramedia Pustaka utama

Skaran.u,(2010) multy variant analisis, Me Growhill.USA

Sugiono,(2008) Populasi pada penelitian Gramedia Pustaka Utama

Santoso,(2001) alat pengukuran uji asumsi klasik.

Suhardi,(2008) $)^{\prime \prime \prime}$ Pengaruh penerapan pertamina way terhadap kepuasan layanan dalam rangka meningkatkan loyalitas"

Teiasih Endah Lestari,(2011) “' kepuasan pelanggan terhadap layanan SPBU pastipas perumusan bekasi timur"

Umar,(2005) Alat ukur Reabilitas, Olah data SPSS

Vaggy Hasra Valonda,(2013) "evaluasi layanan pertamina pas tipasndi SPBU arpin ahmad pekanbaru"

Willam J.Stanto,(1978) Funda mentalis of marketing, Gramedia Pustaka Utama WWW.pertaminapersero.co.id

Zeithaml dan Bitner,(2000) definisi kepuasan konsumen. Gramedia pustaka utama 